\title{
Common Markets Measuring Price Integration in
} European Agricultural Markets

\author{
Crina Viju' ${ }^{1}$, James Nolan ${ }^{2}$, William A. Kerr ${ }^{2}$
}

\begin{abstract}
The accession of Austria, Finland and Sweden to the European Union (EU) is assessed from the perspective of market integration in key agricultural sectors. An empirical investigation is conducted using monthly data for two periods: from 1975:01-1994:12 (the pre-EU period) and 1995:01-2004:12 (post-EU period). The existence of market integration both within the countries and within the EU is tested using time-series methods. A long-run equilibrium between prices for the same good in different markets does not exclude the possibility of short-run deviations in the individual data, so part of this analysis consists of estimating an econometric model (error correction) to uncover long-run effects of price deviations. Only a subset of agricultural prices moves together after EU integration.
\end{abstract}

\footnotetext{
${ }^{1}$ Corresponding author. Department of Agricultural Economics, University of Saskatchewan, 51 Campus Drive, Saskatoon, SK, S7N 5A8. E-mail address: crv058@mail.usask.ca

${ }^{2}$ Department of Agricultural Economics, University of Saskatchewan, Saskatoon, SK, Canada
} 


\section{Introduction}

One of the central economic ideas behind the creation of the EU was that common policies would lead to the integration of various spatially separated product markets. Specifically, the principles of the Common Agriculture Policy (CAP) were designed to ensure that agricultural and food markets in Europe would become integrated. CAP principles support free trade within the EU, and specify common external tariffs and financing. Even after accession to the EU when formal barriers to trade in agricultural goods are removed, in many countries barriers to market integration remained. Among factors that might further impede market integration in EU agriculture markets are the absence of arbitrage mechanisms between markets in the member states, along with residual barriers to efficient arbitrage and imperfect competition in these markets (Zanias, 1993). The effectiveness of regional trade agreements such as the EU is difficult to assess. Market integration, however, is a necessary (but not sufficient) condition for the gains from trade expected from regional trade agreements. If markets are not integrated then prices cannot provide the appropriate signals for resources to be redeployed to provide gains from trade. Hence, examinations of market integration are important for the assessment of the trade agreements. Stylized facts about trade tell us that one of the measurable outcomes resulting from a regional trade agreement is increased market and price integration among member states. Market integration then becomes a necessary, but not sufficient condition describing the movement of resources from inefficient into efficient industries among those countries engaged in trade liberalization. If market integration does not arise, trade-liberalizing initiatives would not function as predicted (Moodley et al. 2000). 
Market integration can be measured in different ways, including the movement of goods or tracking investment flows (Moodley et al, 2000). In this work, our definition of market integration is founded on the economic law of one price (LOP). Markets are considered spatially integrated for a specific good if a causal relationship between prices in different spatial markets can be measured. A stronger version of LOP argues that market prices will eventually equalize between separate regions, when accounting for transport costs, trade restrictions and other transaction costs. We will only try to measure the weaker condition - the stronger conditions for LOP will not be tested here.

A key concept in understanding market integration is spatial price arbitrage: as price increases in one region, this product will eventually be imported into that region from a region with lower prices. This, in turn, leads to a shortage in the exporting region, and, as a result, the good's price increases in the exporting region as well. The possibility of spatial arbitrage explains why prices of homogenous goods can track together in spatially separated markets so long as those markets are integrated in some manner.

Market integration means that a measurable long-run relationship exists between spatially separated prices for the same good. Thus, even when prices might temporarily deviate from each other in the short-run, overall, prices should still be consistent with other integrated markets.

Figure 1 is based on barley prices for Germany and Finland for the period Jan 1995 - Dec 2004 and is an illustration of integrated market prices. Throughout the time period shown, prices in each market follow the same pattern. In the case where LOP is responsible for the price behavior in these markets, the two lines in Figure 1 should overlap. Conversely, Figure 2 is based on rye prices in Germany and Finland for the 
period Jan 1975 - Dec 1994, and is an example of non-integrated market prices. It is easy to see that the two price series in Figure 2 possess distinct patterns over the chosen time interval.

Figure 1

Example of integrated markets

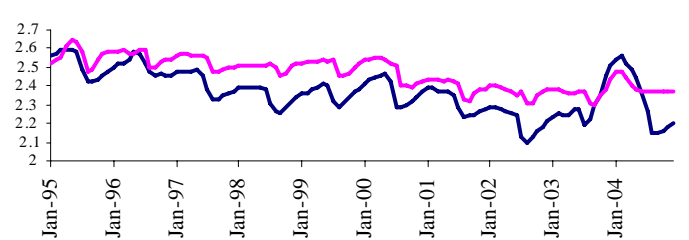

Figure 2

Example of non-integrated markets

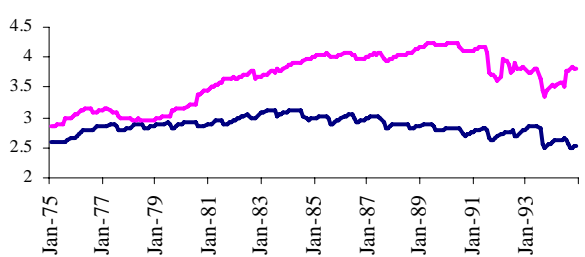

Source: author's calculations

To date, most applied econometric trade studies have concentrated on testing market integration rather than adherence to the LOP. Considering LOP, we offer that prices of similar goods actually moving together across spatially distinct markets is a better indication of market integration than examining whether or not prices equalize across regions. Since this issue is important for measuring the success of trade policy, the aim of this paper is to examine price movements in several agricultural markets for countries that recently joined the European Union (EU) in the same year.

With respect to these countries, this represents the first study drawing upon LOP to document how key agricultural markets were affected by joining the EU. In this light, the empirical investigation will consist of two parts. In the first part, we address the following issues: 1) Are agricultural markets in these three new acceding countries integrated with those in the EU?; and 2) Is there evidence of market integration in the 
Review of European and Russian Affairs vol. 2 issue 1/2006 @ RERA 2006 all rights reserved

pre-EU and/or post-EU period? The second part of this study will concentrate on the analysis of the acceding countries individually to determine if their agricultural markets were integrated with the other acceding countries in the pre-EU and/or post-EU period.

The paper is organized as follows. Section II highlights the most important characteristics of the agri-food sector in the three European countries (Austria, Finland and Sweden). Section III reviews contributions to this literature. Section IV presents the empirical methodology, while Section $\mathrm{V}$ describes the data used in the analysis. In Section VI the empirical results are described and the paper ends with a series of concluding remarks.

\section{The EU Agricultural Sector}

The primary objective for creating a common agricultural market within the EU was to facilitate movement of goods and factors of production between EU member states. It was this idea of a common market that influenced the initial design of CAP. CAP was established in 1957 and it was focused on the development of a set of common policy instruments along with setting common prices (i.e. target, threshold and intervention prices). Common prices were set with respect to a common currency and this situation influenced each member country in different ways, with specific effects depending on market exchange rates.

Monetary Compensatory Amounts (MCA's) were introduced in the EU and became a means to tax or subsidize exports, compensating for currency fluctuations and facilitating agricultural trade among the EU countries (Zanias, 1993). MCA's were used for more than twenty years and preserved protection levels in member states at previous 
exchange rates, thus impeding free trade and market integration. Even though they were supposed to be temporary measures, MCA's became a source of conflict among the member countries. This situation was solved only when the member states converged to become a Monetary Union.

Through the McSharry reforms of 1992, guaranteed agricultural prices were replaced with a new system of direct compensating payments for farmers, activated if prices fell below a certain level. CAP was further reformed under Agenda 2000. These reforms came into effect in March 2003 and production subsidies were replaced with a set of direct payments, linked with standards on food safety, animal rights and environmental concerns. The newest element of this latest reform is the introduction of the "Single Farm Payment", which replaces a vast array of extant direct payment schemes.

To date, there have been some problems with the accession process in the EU agricultural sector. These stem from differential levels of farm support along with particular regional circumstances, including extreme climate and geophysical conditions which characterize agriculture in some acceding countries. For this study, we note that Austria, Finland and Sweden became full members of EU in 1995.

Austria is one of the wealthiest European countries, with an economy of a highly developed nation possessing an important service sector (65\% in 2002). Just $17 \%$ of Austria is arable land, a fact that motivates highly intensive forms of crop production. In fact agriculture does not play a very important role in the economy of the country, accounting only for $2 \%$ of GDP. As shown in Annex A, Table A1, for the agricultural products considered in this analysis, rye accounts for the highest production in Austria as 
a percentage of production in EU-15. Traditionally, Austria is an agri-food importer, but in recent years its agri-food exports increased faster than its imports. The main trading partners for Austrian agri-food products are its EU neighbors. Germany is at the top of this list, accounting for $42 \%$ of Austrian imports and $35.9 \%$ of exports in 2003 (Agriculture and Agri-Food Canada, 2004).

Finland is the northernmost agricultural producer in the EU, and only $6 \%$ of the total land area is considered to be arable. The main crops produced in Finland are barley and oats (Annex A, Table A2). Due to its climate, agriculture does not occupy an important role in the Finnish economy, contributing to about 3\% of the GDP (Agriculture and Agri-Food Canada, 2004). The main trading partner for Finnish agri-food products is also Germany.

Finally, Sweden is the third largest country in Western Europe, but is has only 6\% total arable land. Crop production is dominant in central Sweden, with the main crops produced being cereals and fodder crops. As can be seen in Annex A, Table A3, barley, wheat and oats represent the main crops produced in Sweden. Agriculture accounts for just 2\% of GDP (Agriculture and Agri-Food Canada, 2004). The most important trading partners are EU countries such as Denmark, the Netherlands, Norway and Germany.

The accession to EU affected the agricultural sector of these three countries in different ways. Firstly, under the Accession Agreement, new members had to adjust their prices to EU levels. This adjustment caused a price drop of about 40 to 45 percent in the cereal, livestock and dairy sectors in Austria and Finland. The situation was different in Sweden, where agricultural support declined significantly after 1991 and the gap between 
domestic and international prices was smaller. ${ }^{3}$ After accession, in Sweden cereal prices increased, dairy prices remained stable, while in the livestock sector prices decreased sharply. Secondly, as a result of lowered prices for agricultural products, farmers in the three new EU member countries faced increased competition from more efficient EU producers.

Note that the EU is by far the largest single exporter of rye, with the vast majority of production coming from Germany. For this reason, rye production has become an important issue for EU policymakers, with intervention price support for rye being $€ 101.31 / t$ in 2001-2002 - the same as the intervention price for wheat and barley. The major exporters of barley are the EU, Russia and the Ukraine. Among EU producers of barley, most production comes from France, Germany and Spain.

Unlike the situation for wheat, barley and rye, the EU does not offer an intervention price nor maintain intervention stocks for oats. However, in recognition of the importance of the oats trade to Sweden and Finland, special provisions were made when they joined the EU for subsidies on their oats exports (as of 1997). Oats are still a very thinly traded commodity, being used mostly on farm for animal feed in country of origin. However, human consumption is an important part of distribution in the UK, Germany and the US. Within the EU, trade of oats is mostly limited to intra-EU trade and exports from Finland and Sweden to the US (Agriculture and Agri-Food Canada, 2000, 2001, 2002, 2003, 2004).

\footnotetext{
${ }^{3}$ Sweden reduced its agricultural support primarily due to currency devaluation in this time period.
} 
Review of European and Russian Affairs vol. 2 issue 1/2006 @ RERA 2006 all rights reserved

\section{Price transmission and market integration}

Some of the international trade literature evaluates market integration across countries by testing the law of one price (LOP) or absolute purchasing power parity (PPP) at an aggregate level (Casel, 1918). LOP is based on international commodity arbitrage in efficient markets, implying that every good has a single price that can be expressed in a common currency throughout the world (Isard, 1977). PPP also implies that by aggregating all goods, an overall price index computed between two countries should be the same after conversion to a common currency. However, many studies have shown that the strict price behavior implied by LOP is not often observed in reality.

Ardeni (1989) showed that one of the shortcomings of earlier empirical studies in finding evidence that supports perfect arbitrage for commodity prices is the failure to consider the time-series properties of the variables (i.e. identical joint distributions throughout the data) and by the improper use of transformations on these variables. The failure of LOP in this study is explained by institutional factors, including the cost of arbitrage, errors in data and in the definition of prices.

Subsequently, Engel (1993) measured the variation in the price of identical goods across countries and the variation of different goods within a country. He showed that the first type of variation, which represents the failure in the LOP is usually larger than the second variation. Engel and Rogers (1996) found some explanation for deviations from LOP observed in the data. They found that the distance between markets explains most of the variation in prices of similar goods in different areas. When considering two cities located in different countries, the variation of the prices is much higher than for two 
equidistant cities in the same country. They suggest this could be due to sticky nominal prices.

Another large body of research has applied various quantitative techniques to more accurately measure market and price integration. Gordon et al. (1993) examined the nature of integration for the British and French lamb market during the period 1983-1986. To test for price integration, they employed a time series causality test. They reached the conclusion that the markets are integrated for the specified period, but the response of one price to the change in the other price was surprisingly slow. Slow adjustments in prices were explained by non-tariff barriers, differences in product quality, as well as uncertainty surrounding the final price received. Zanias (1993) tested LOP using time series data on four agricultural products produced within the European Community. The products chosen (soft wheat, dairy milk, potatoes and pig carcasses) are very different in terms of product characteristics and associated policy framework. Zanias found that a single price existed in soft wheat markets, but suggested this was the result of minimum intervention prices and efficient arbitrage. With milk, the markets were found to be nonintegrated. This result was explained by the importance of non-tariff barriers in milk markets and by imperfect competition in this industry. For potatoes and pig carcasses, the lack of consistent data series did not allow the inclusion of much data, so these results differed from case to case.

Diakosavvas (1995) examined agricultural market integration by looking at Australian and U.S. beef prices at the farmgate level. He tested for price cointegration using a time-varying parameter estimation procedure. His analysis found that the two markets are cointegrated (although not fully), whereas the time-varying procedure 
indicated that the convergence between prices did not increase substantially over time. He concluded that Australian beef prices could not be used as a proxy for a world price for empirical analysis.

With respect to North American market integration, Moodley et al. (2000) evaluated the Canada-US Trade Agreement (CUSTA). Previous work indicated that markets in the US and Canada were not integrated before CUSTA, so this empirical work addressed two basic questions - were these markets integrated, and was there evidence of market convergence after CUSTA? The latter could be interpreted as evidence that the trade agreement had critical effects on the product markets. Their analysis found that a cointegrated price system existed after the introduction of CUSTA. Additionally, their approach showed that price convergence occurred before the introduction of CUSTA, leading them to conclude that it was likely easier to ratify CUSTA given that many of the expected trade adjustments in these markets had already taken place. With respect to agriculture, Mohanty and Langley (2003) examined grain (wheat and barley) price integration between the US and Canada. They tested whether policy changes, such as the North American Free Trade Agreement (NAFTA) and the Western Grain Transportation Act (WGTA) affected the degree of integration between these grain markets. They found that these markets are in fact integrated, and that the post-NAFTA and post-WGTA periods were characterized by improved market integration.

Finally, a number of studies on market integration and price transmission (both spatially and vertically) have highlighted several factors that impede price transmission. For example, border and domestic policies, in the form of price support mechanisms, weaken any link between international and domestic markets. Different agricultural 
policy instruments as well as exchange rate policies hinder the full transmission of international price signals (Knetter, 1993). Other policies among the border measures are non-tariff barriers, which may have strong effects on price transmission through space (Zanias, 1993; Thompson et. al., 2002).

Apart from policies, domestic markets can also be partly insulated by large marketing margins that arise due to high transport and transaction costs. This factor can have strong effects, especially in developing countries where poor infrastructure and transport services give rise to large marketing margins due to high costs of delivering traded commodities. High transfer costs hinder the transmission of price signals, and they may prevent or discourage goods arbitrage (Sexton, Kling and Carman, 1991; Badiane and Shively, 1998). Market power can also hinder market integration, in the sense that the price differences between international and domestic prices may be higher than those determined by transfer costs alone (Dhar and Cotteril, 1998). This literature also concentrates on the extent to which changes in exchange rates facilitate price discrimination (i.e. charging different customers different prices) among destinations (Froot and Klemperer, 1989; Knetter, 1993).

\section{Testing for integrated or common markets - empirical methodology}

Cointegration tests and error correction models are modern statistical tools that help analyze price movements beyond the simple case of market integration or complete price transmission across markets. These specifications allow us to test notions such as completeness, speed, and asymmetry of the relationship between agricultural prices in various countries. 
Listing producer prices $\mathrm{p}_{\text {taus }}, \mathrm{p}_{\text {tfin }}, \mathrm{p}_{\text {tsw }}$ and $\mathrm{p}_{\text {teu }}$ for each agricultural product in the three countries under study and in the EU, and with $\mathrm{e}_{\text {aus }}$, $\mathrm{e}_{\mathrm{fin}}$, and $\mathrm{e}_{\mathrm{sw}}$ listed as the corresponding exchange rates, the following price series are tested for statistical cointegration:

$P_{\text {aus }}=f\left(P_{\text {eu }}\right), P_{\text {fin }}=f\left(P_{\text {eu }}\right), P_{\text {sw }}=f\left(P_{\text {eu }}\right)$ and $P_{\text {fin }}=f\left(P_{\text {aus }}, P_{\text {sw }}\right)$

where :

$P_{\text {aus }}=\ln \left(e_{\text {aus }} p_{\text {taus }}\right), P_{\text {fin }}=\ln \left(e_{\text {fin }} p_{\text {tfin }}\right)$

$P_{\text {sw }}=\ln \left(e_{\text {sw }} p_{\text {tsw }}\right), P_{\text {eu }}=\ln \left(p_{\text {teu }}\right)$

Given that the data employed in the analysis need to be expressed in logarithms, the estimated parameters can be directly interpreted as "transmission elasticities” for one price with respect to another. Cointegration or co-movement of these commodity prices across countries can be tested using econometric time-series techniques. Statistical cointegration analysis consists of two steps. First, the cointegrating relationship is investigated to see if prices are related by a long-run relationship. Second, in order to determine if two countries belong to the same market, an adjustment process to short-run shocks must also be investigated.

As a specialized technique with specific structural assumptions about data, cointegration analysis (Engle and Granger, 1987) is preceeded by tests for nonstationary variables. Specifically, if a linear combination of integrated variables is stationary, the variables are said to be co-integrated. In turn, the cointegrated vector defines the long-run relationship among the nonstationary variables. Cointegration does not mean that 
variables cannot deviate from a long-run equilibrium, but deviations will usually be temporary and market forces will bring the variables to their cointegrated equilibrium.

There are two commonly used methods to test for cointegration. There is the wellknown Engle and Granger (1987) methodology, which determines whether the residuals of the equilibrium relationship are stationary, while the Johansen (1988) and StockWatson (1988) methodologies determine the number of the cointegrated vectors. For this analysis, the Johansen procedure will be used to determine if a long-run relationship between the prices under consideration exists.

It is also well known that such results are quite sensitive to the data lag structure in the model. Most commonly, one estimates a vector autoregression using undifferenced data, and then a set of statistical tests (Akaike, Schwartz or Hannan-Quinn Information Criteria) $)^{4}$ facilitate the choice of the right lag length in the time series equation. The last two tests are preferred because they are more accurate when more variables bet introduced in to a model.

Finding a cointegrated system does not exclude the possibility of observing shortrun deviation of the individual series. The short-run dynamics of prices are often modeled using an error-correction statistical model (ECM). In turn, vector autoregression (VAR) ${ }^{5}$ is commonly used for forecasting systems of interrelated time series. A vector error correction (VEC) model is a restricted VAR that has cointegration restrictions built into the specification. Finally, the VEC specification used here restricts the long-run behavior of the endogenous variables to converge to their cointegrating relationships while allowing a certain amount of short-run dynamics.

\footnotetext{
${ }^{4}$ See Akaike (1974,1976), Schwartz (1978) and Hannan-Quinn (1979)

${ }^{5}$ See Greene (2003)
} 


\section{Data Description}

Empirical analysis is conducted for a few key agricultural commodities from Austria, Sweden and Finland. We study price movements in rye, soft wheat, barley, oats and potatoes. The first four products listed are heavily supported by CAP, while the fifth product (potatoes) is not.

The absolute producer price series comprise monthly data, collected for a period of thirty years, from 1975:1 - 2004:12. The data for 1975:1 - 1994:12 were obtained from the boards of agriculture in each country and were expressed in their respective national currencies. For the period 1995:1 - 2004:12, the data were extracted from Eurostat and were expressed in EUROS. The data were all converted to ECUs using the market exchange rates from Eurostat. One additional characteristic of the data is that from 1999:1, Austria and Finland joined the monetary union, while Sweden kept its own currency. So starting with 1999:1, the prices in Austria and Finland are expressed in EUROS at the fixed exchange rate, while the prices in Sweden are expressed using a flexible market exchange rate.

Since the first question to be addressed is whether the three acceding countries' markets and the EU market are integrated, a reference EU producer price should be used. As there is no dominant EU price, we chose German producer prices because Germany is clearly the most important trading partner for the three countries. The producer price series for Germany were loaded from Eurostat and are expressed in ECU until 1995, and in EUROS after 1995. 


\section{Empirical results}

To be able to conduct a cointegration test on prices, the individual price series need to be tested for stationarity - the techniques described above only work with nonstationary data. Tests revealed that four out of the five products under consideration are non-stationary: rye, soft wheat, barley and oats. Some additional data transformations are necessary to estimate equations to describe price movements for these products.

With respect to cointegration between each new acceding country’s product price and prices in Germany, a Johansen test did not reject the null hypothesis of zero cointegrating vectors for the pre-EU sample period. The only exception was found with the price pair $\left(\mathrm{P}_{\mathrm{GER}}, \mathrm{P}_{\mathrm{AUS}}\right)$ in the case of rye, soft wheat and barley. In these cases, the null was rejected, providing evidence that these product prices were cointegrated even before Austria joined the EU.

For the post-EU period, a null hypothesis of zero cointegrating vectors was rejected in many of the cases. The only cases for which cointegration was not observed were for the pair $\left(\mathrm{P}_{\mathrm{GER}}, \mathrm{P}_{\mathrm{FIN}}\right)$ for soft wheat, along with price pairs $\left(\mathrm{P}_{\mathrm{GER}}, \mathrm{P}_{\mathrm{FIN}}\right)$ and $\left(\mathrm{P}_{\mathrm{GER}}\right.$, $\mathrm{P}_{\mathrm{SW}}$ ) for oats. Such results are evidence of strong agricultural price cointegration after the three countries joined EU. With the exception of oats, where price cointegration appears only for Austria, for the rest of the chosen products, producer prices in the three countries share a long-run relationship with the EU price $\left(\mathrm{P}_{\mathrm{GER}}\right)$. Convergence in prices might also be influenced by minimum intervention prices (Zanias, 1993), even price supports were reduced as a result of the MacSharry (Hubbard and Ritson, 1997) and Agenda 2000 (van Meijl, 2002) reforms. 
An interesting situation concerns the cointegration results among the three acceding countries. The producer prices in these countries do not share a long-run equilibrium in the two periods - evidence of almost no market integration (except for soft wheat in the post-EU period). This could be explained by the fact that producer prices in the three acceding countries were highly supported by governments in the pre-EU period, so these prices were not the result of market forces. As small agricultural markets, when joining the EU these countries suddenly had access to wider markets and the price discipline that followed. As well, consider that each of these countries increased agricultural trade with former Eastern European countries around the time of their EU integration (Breuss, 2005).

There still exists the possibility that producer prices in each country's market can temporarily deviate from long-run equilibrium. Such short-run dynamics can be examined by estimating a Vector Error Correction (VEC) model on the data.

Rye prices in the EU and the three acceding countries are in fact cointegrated, meaning that these markets have a strong long run relationship. This supports our supposition about the structure of an integrated European market for certain agricultural products. Examining the short run response to the long run equilibrium we found that, in general, price adjustments are very quick.

In the case of soft wheat, there is evidence of market integration except for Finland. Examining short-run dynamics, speed of price adjustment increased in the postEU period compared with the pre-EU period. For the pair of (Germany, Austria) there was evidence of market integration before Austria joined the EU. This implies that prices were in the process of converging prior to joining the EU (Moodley et.al., 2000). Finally, 
results from the error correction model show that price adjustment was faster in the postEU period, while the level of market integration has decreased.

Prices of barley are cointegrated in the post-EU period, and we interpret this as evidence of long-run equilibrium. With respect to the short-run dynamics, in general, there is no evidence of adjustment (the parameter estimates are statistically insignificant), while the European market for oats did not actually become integrated with the inclusion of these countries into the EU.

\section{Summary and conclusions}

The study of market integration is important with respect to evaluating the success of particular trade agreements. The process of price transmission from one market to another is central in understanding the extent of the integration of economic agents into the market process. Conversely, the absence of market integration has important implications for economic welfare. Incomplete price transmission arises from either trade barriers or other protectionist policies, or can be due simply to transaction costs such as poor transport and communication infrastructure. This results in a reduction in the price information available to economic agents and consequently can lead to decisions that contribute to economically inefficient outcomes.

In theory, spatial price determination models suggest that if two markets are linked by trade in a free market regime, excess demand or supply shocks in one market will have an equal impact on price in both markets. In general, the existence of import tariffs allows price changes to be fully transmitted to other markets in relative terms. However, with a prohibitively high tariff, changes in one price would be only partly (if at 
all) transmitted to the other market. Furthermore, this price will likely be close to the autarky (no trade) price level and will prohibit all opportunities for spatial arbitrage. Regarding price support policies such as intervention mechanisms and floor prices, changes in one price will have no effect on the other market only when the price falls below that level at which the floor price has been set. However, any changes in the price above the floor price level will be transmitted to the other market. Apart from such policies, there are other factors that can impede market integration, as high transfer costs and non-competitive behavior.

The primary objective for the formation of CAP was the integration of agricultural markets in this spatial sense. The Treaty of Rome from 1958 established that "The Common Market shall extend to agriculture and trade in agricultural products" (Article 38) and eventually, all the barriers to trade between member states will be eliminated (Ritson, 1997). In turn, the two guiding principles of the Single European Market (SEM) are non-discrimination and mutual recognition. As mutual recognition proved to be insufficient, common harmonization directives were adopted. These were focused on health, safety, and environmental protection. Finally, an important obstacle for the existence of increased market integration is the insistence of some member states (especially the UK) on having national sovereignty over important macroeconomic matters (e.g. monetary policy, fiscal measures).

CAP contributes to a more ideal market environment for arbitrage activities. Operation at a minimum price might influence convergence in prices, even thought this situation would not likely be observed without markets being linked through arbitrage 
(Colman, 1985). Therefore, as long as prices are above the intervention price level, finding cointegrated prices in a statistical sense is strong evidence of market integration.

In this paper, the accession of Austria, Finland and Sweden to the European Union (EU) is assessed from the perspective of market integration in several agricultural sectors. To our knowledge, the agricultural sectors of these countries have never been studied before in this respect. The analysis addresses two important questions in this regard - 1) are markets in these three acceding countries integrated with those in the EU; and 2) are these markets integrated with each other? Note that if we found market integration emerging in the post-EU period, this is evidence that the accession to the single market had an important effect on these agricultural goods markets.

Our empirical investigation examined a set of important agricultural products (rye, soft wheat, barley, oats and potatoes) for two periods. The sub-samples include the time from 1975:01-1994:12 (pre-EU period) and 1995:01-2004:12 (post-EU period). The existence of market (price) integration both within the countries and within the EU is tested using time-series econometrics.

In the pre-EU period, cointegration among prices was discovered for rye, soft wheat and barley between Austria and Germany, while in the post-EU period, rye and barley markets proved to be most tightly integrated with the German (EU) market. The oats market was the least integrated in the sample. And regarding market integration among the three acceding countries, we found no evidence that prices among these commodities share a common long-run equilibrium.

Even though the countries under study were part of the European Free Trade Agreement (EFTA) before joining EU, there was certainly no evidence of market 
integration for agricultural products in the pre-EU period. Based on our findings, we expect that the situation would be the same in case of the Central and Eastern European countries (CEEC), which joined EU in 2004 (plus Romania and Bulgaria in 2007). However, the situation in these latter countries is different compared to our sample in three ways. Firstly, agriculture makes up a large share of employment - the two largest CEEC countries alone (Poland and Romania) contain almost half the agricultural area as the EU-15. Secondly, CAP would clearly be applied in stages to the new members over a ten-year period, rendering the transition as smooth as possible. Lastly, CAP itself will be reformed further as a result of World Trade Organization’s (WTO) liberalizing measures pertaining to agriculture. 


\section{Bibliography}

Agriculture and Agri-Food Canada. “Agri-Food Trade Synopsis - Austria.” (September, 2004). http://ats-sea.agr.gc.ca/europe/3936_e.htm.

Agriculture and Agri-Food Canada. "Finland and Sweden: oats." Bi-weekly Bulletin 17/7(2004). http://www.agr.gc.ca/mad-dam/e/bulletine/v17e/v17n07_e.htm.

Agriculture and Agri-Food Canada. "Feed barley: 2003-2004 outlook.” Bi-weekly Bulletin16/19(2003).http://www.agr.gc.ca/maddam/e/bulletine/v16e/v16n19 e.htm

Agriculture and Agri-Food Canada. "Rye: situation and outlook." Bi-weekly Bulletin 15/12(2002). http://www.agr.gc.ca/mad-dam/e/bulletine/v15e/v15n12e.htm.

Agriculture and Agri-Food Canada. "Barley.” Bi-weekly Bulletin 14/10(2001). http://www.agr.gc.ca/mad-dam/e/bulletine/v14e/v14n10e.htm

Agriculture and Agri-Food Canada. "Wheat: situation and outlook." Bi-weekly Bulletin13/17(2000).http://www.agr.gc.ca/maddam/e/bulletine/v13e/v13n17e.htm

Akaike, H. “A New Look at the Statistical Model Identification.” I.E.E.E. Transactions on Automatic Control, AC 19(1974):716-723.

Akaike, H. "Canonical Correlation Analysis of Time Series and the Use of an Information Criterion." in R.K. Mehra and D.G. Lainotis (eds.). System Identification: Advances and Case Studies. Academic Press, New York. 1976: 52107.

Ardeni, P.G. "Does the Law of One Price Really Hold for Commodity Prices?” American Journal of Agricultural Economics 71(1989): 661-669.

Badiane, O. and Shively, G.E. "Spatial Integration, transport costs and the response of local prices to policy changes in Ghana.” Journal of Development Economics 56(1998):411-431.

Breuss, F. "Austria, Finland and Sweden after 10 Years in the EU: Expected and Achieved Integration Effects.” EUROPAINSTITUTE, University of Economics and Business Administration Vienna, working paper 65(2005), http://fgr.wuwien.ac.at/institut/ef/publicat.html.

Casel, G. “Abnormal Deviations in International Exchanges.” Economic Journal 28(1918): 413-415. 
Colman, D. "Imperfect transmission of policy prices." European Review of Agricultural Economics 12(1985/86): 171-186.

Dhar T. and Cotterill, R.W. "A structural approach to price transmission in non competitive market channels: a study on the fluid milk market.” Draft ERS (1998).

Diakosavvas, D. "How integrated are world beef markets? The case of Australian and U.S. beef markets.” Agricultural Economics 12(1995):37-53.

Engel, C. "Real exchange rates and relative prices: An empirical investigation.” Journal of Monetary Economics 32(1993): 35-50.

Engel, C. and Rogers, J.H. "How Wide Is the Border?" American Economic Review 86(1996): 1112-1125.

Engle, R.E. and Granger C.W.F.. "Cointegration and Error-Correction: Representation, Estimation and Testing." Econometrica 55(1987): 251-76.

Froot, A.K. and Klemperer, P.D. 1989. "Exchange rates pass-through when market share matters.” American Economic Review 79(1989):637-654.

Gordon, D.V., Hobbs, J.E. and Kerr, W.A. "A test for price integration in the EC lamb market.” Journal of Agricultural Economics 44(1993):126-134.

Greene, W. “Econometric Analysis.” Prentice Hall, 5"h Edition, 2003.

Hannan, E.J. and Quinn, B.G. "The Determination of the Order of an Autoregression.” Journal of the Royal Statistical Society, B 41 (1979): 190-195.

Hubbard, L. and Ritson, C. "Reform of the CAP: from Mansholt to Mac Sharry." in Ritson, C, Harvey, D (Eds). The Common Agricultural Policy. CAB International, Wallingford ch. 4(1997): pp.81-94.

Johansen, S. "Statistical Analysis of Cointegration Vectors." Journal of Economic Dynamics and Control 12(1988): 231-254.

Knetter, M.M. "International comparison of pricing-to-market behavior.” American Economic Review June(1993): 423-436.

Isard, P. "How far can we push the "Law of One Price"?" The American Economic Review 67(1977): 942-948.

Mohanty, S. and Langley, S. "The Effects of Various Policy Regimes in the Integration of North American Grain Markets.” Canadian Journal of Agricultural Economics 51(2003):109-120. 
Moodley, D., Kerr, W.A. and Gordon, D.V. "Has the Canada-US Trade Agreement Fostered Price Integration?” Review of World Economics 136(2000): 334-354.

Ritson, C. "Introduction to the CAP.” in C. Ritson and D.R. Harvey (eds.). The Common Agricultural Policy. Wallingford: CAB International 1997.

Schwartz, G. "Estimating the Dimension of a Model." Annals of Statistics 6 (1978): 461464.

Sexton, R., Kling, C. and Carman, H. "Market integration, efficiency of arbitrage and imperfect competition: methodology and application to US celery." American Journal of Agricultural Economics 73(1991):568-580.

Stock, J. and M. Watson. "Testing for common trends." Journal of the American Statistical Association 83(Dec. 1988): 1097-1107.

Thompson R.S, Sul, D. and Bohl, M. T.. "Spatial market efficiency and policy regime change: Seemingly unrelated error correction model estimation.” American Journal of Agricultural Economics 84(2002): 1042-1053.

Van Meijl, H. and van Tongeren, F. "The Agenda 2000 CAP reform, world prices and GATT-WTO export constraints.” European Review of Agricultural Economics 29(4)(2002): 445-470.

Zanias, G.P. "Testing for integration in European Community agricultural product markets.” Journal of Agricultural Economics. 44(1993): 418-427. 


\section{ANNEX A}

Table A.1: Production of agricultural commodities in Austria (1990-2005) as percentage of production in EU-15

\begin{tabular}{|c|c|c|c|c|c|c|c|c|c|c|c|c|c|c|c|c|}
\hline AUSTRIA & 1990 & 1991 & 1992 & 1993 & 1994 & 1995 & 1996 & 1997 & 1998 & 1999 & 2000 & 2001 & 2002 & 2003 & 2004 & 2005 \\
\hline Cereals & $2.68 \%$ & $2.56 \%$ & $2.39 \%$ & $2.34 \%$ & $2.52 \%$ & $2.48 \%$ & $2.62 \%$ & $2.40 \%$ & $2.24 \%$ & $2.36 \%$ & $2.08 \%$ & $2.39 \%$ & $2.22 \%$ & $2.25 \%$ & $2.32 \%$ & $2.14 \%$ \\
\hline $\begin{array}{c}\text { Soft wheat } \\
\text { and spelt }\end{array}$ & $1.64 \%$ & $1.60 \%$ & $1.62 \%$ & $1.28 \%$ & $1.57 \%$ & $1.57 \%$ & $1.44 \%$ & $1.49 \%$ & $1.35 \%$ & $1.48 \%$ & $1.33 \%$ & $1.76 \%$ & $1.47 \%$ & $1.38 \%$ & $1.62 \%$ & $1.49 \%$ \\
\hline $\begin{array}{c}\text { Rye and } \\
\text { meslin }\end{array}$ & $7.16 \%$ & $7.44 \%$ & $7.73 \%$ & $6.83 \%$ & $7.03 \%$ & $5.28 \%$ & $2.81 \%$ & $3.48 \%$ & $3.76 \%$ & $4.05 \%$ & $3.41 \%$ & $3.47 \%$ & $3.71 \%$ & $4.33 \%$ & $4.56 \%$ & $4.67 \%$ \\
\hline Barley & $2.73 \%$ & $2.52 \%$ & $2.85 \%$ & $2.32 \%$ & $2.72 \%$ & $2.45 \%$ & $2.06 \%$ & $2.40 \%$ & $2.35 \%$ & $2.37 \%$ & $1.66 \%$ & $2.11 \%$ & $1.79 \%$ & $1.89 \%$ & $1.94 \%$ & $2.02 \%$ \\
\hline $\begin{array}{c}\text { Oats and } \\
\text { summer } \\
\text { cereal } \\
\text { mixture }\end{array}$ & $3.54 \%$ & $3.68 \%$ & $3.79 \%$ & $3.17 \%$ & $3.02 \%$ & $3.09 \%$ & $2.58 \%$ & $3.24 \%$ & $2.94 \%$ & $2.93 \%$ & $2.02 \%$ & $2.37 \%$ & $1.85 \%$ & $2.10 \%$ & $2.30 \%$ & $2.48 \%$ \\
\hline Potatoes & $1.61 \%$ & $1.75 \%$ & $1.45 \%$ & $1.83 \%$ & $1.42 \%$ & $1.66 \%$ & $1.53 \%$ & $1.42 \%$ & $1.50 \%$ & $1.47 \%$ & $1.43 \%$ & $1.55 \%$ & $1.48 \%$ & $1.37 \%$ & $1.45 \%$ & $1.59 \%$ \\
\hline
\end{tabular}

Source: EUROSTAT

Table A.2: Production of agricultural commodities in Finland (1990-2005) as percentage of production in EU-15

\begin{tabular}{|c|c|c|c|c|c|c|c|c|c|c|c|c|c|c|c|c|}
\hline FINLAND & 1990 & 1991 & 1992 & 1993 & 1994 & 1995 & 1996 & 1997 & 1998 & 1999 & 2000 & 2001 & 2002 & 2003 & 2004 & 2005 \\
\hline Cereals & $2.18 \%$ & $1.74 \%$ & $1.43 \%$ & $1.85 \%$ & $1.93 \%$ & $1.85 \%$ & $2.06 \%$ & $1.82 \%$ & $1.30 \%$ & $1.41 \%$ & $1.89 \%$ & $1.81 \%$ & $1.84 \%$ & $1.99 \%$ & $1.58 \%$ & $1.79 \%$ \\
\hline $\begin{array}{c}\text { Soft wheat } \\
\text { and spelt }\end{array}$ & $0.77 \%$ & $0.52 \%$ & $0.27 \%$ & $0.47 \%$ & $0.44 \%$ & $0.47 \%$ & $0.55 \%$ & $0.53 \%$ & $0.42 \%$ & $0.28 \%$ & $0.56 \%$ & $0.59 \%$ & $0.60 \%$ & $0.83 \%$ & $0.78 \%$ & $0.85 \%$ \\
\hline $\begin{array}{l}\text { Rye and } \\
\text { meslin }\end{array}$ & $4.14 \%$ & $0.56 \%$ & $0.68 \%$ & $1.33 \%$ & $0.44 \%$ & $0.93 \%$ & $1.50 \%$ & $0.78 \%$ & $0.77 \%$ & $0.43 \%$ & $1.96 \%$ & $1.01 \%$ & $1.52 \%$ & $2.23 \%$ & $1.27 \%$ & $0.96 \%$ \\
\hline Barley & $3.09 \%$ & $3.15 \%$ & $2.82 \%$ & $3.55 \%$ & $4.26 \%$ & $4.06 \%$ & $3.53 \%$ & $3.83 \%$ & $2.55 \%$ & $3.22 \%$ & $3.86 \%$ & $3.71 \%$ & $3.62 \%$ & $3.64 \%$ & $3.32 \%$ & $4.71 \%$ \\
\hline $\begin{array}{c}\text { Oats and } \\
\text { summer } \\
\text { cereal } \\
\text { mixture }\end{array}$ & $18.69 \%$ & $14.70 \%$ & $16.50 \%$ & $16.18 \%$ & $16.16 \%$ & $17.63 \%$ & $16.94 \%$ & $17.30 \%$ & $14.49 \%$ & $15.47 \%$ & $19.84 \%$ & $19.68 \%$ & $20.13 \%$ & $18.07 \%$ & $14.57 \%$ & $19.84 \%$ \\
\hline Potatoes & $1.79 \%$ & $1.48 \%$ & $1.32 \%$ & $1.61 \%$ & $1.73 \%$ & $1.83 \%$ & $1.52 \%$ & $1.58 \%$ & $1.37 \%$ & $1.64 \%$ & $1.62 \%$ & $1.64 \%$ & $1.69 \%$ & $1.51 \%$ & $1.30 \%$ & $1.54 \%$ \\
\hline
\end{tabular}


Table A.3: Production of agricultural commodities in Sweden (1990-2005) as percentage of production in EU-15

\begin{tabular}{|c|c|c|c|c|c|c|c|c|c|c|c|c|c|c|c|c|}
\hline SWEDEN & 1990 & 1991 & 1992 & 1993 & 1994 & 1995 & 1996 & 1997 & 1998 & 1999 & 2000 & 2001 & 2002 & 2003 & 2004 & 2005 \\
\hline Cereals & $3.29 \%$ & $2.64 \%$ & $2.05 \%$ & $2.80 \%$ & $2.42 \%$ & $2.67 \%$ & $3.32 \%$ & $2.87 \%$ & $2.64 \%$ & $2.42 \%$ & $2.62 \%$ & $2.66 \%$ & $2.55 \%$ & $2.82 \%$ & $2.41 \%$ & $2.22 \%$ \\
\hline $\begin{array}{c}\text { Soft wheat } \\
\text { and spelt }\end{array}$ & $2.76 \%$ & $1.79 \%$ & $1.79 \%$ & $2.27 \%$ & $1.74 \%$ & $1.93 \%$ & $2.45 \%$ & $2.35 \%$ & $2.38 \%$ & $1.86 \%$ & $2.51 \%$ & $2.82 \%$ & $2.24 \%$ & $2.78 \%$ & $2.40 \%$ & $2.42 \%$ \\
\hline $\begin{array}{c}\text { Rye and } \\
\text { meslin }\end{array}$ & $5.67 \%$ & $3.27 \%$ & $3.49 \%$ & $4.87 \%$ & $3.42 \%$ & $3.33 \%$ & $2.87 \%$ & $2.28 \%$ & $2.50 \%$ & $2.12 \%$ & $3.39 \%$ & $2.85 \%$ & $2.67 \%$ & $3.62 \%$ & $2.72 \%$ & $3.02 \%$ \\
\hline Barley & $3.81 \%$ & $3.42 \%$ & $2.67 \%$ & $3.53 \%$ & $3.81 \%$ & $4.13 \%$ & $4.01 \%$ & $3.98 \%$ & $3.27 \%$ & $3.80 \%$ & $3.18 \%$ & $3.42 \%$ & $3.70 \%$ & $3.32 \%$ & $3.26 \%$ & $3.68 \%$ \\
\hline $\begin{array}{c}\text { Oats and } \\
\text { summer } \\
\text { cereal } \\
\text { mixture } \\
\end{array}$ & $19.62 \%$ & $20.22 \%$ & $14.57 \%$ & $18.32 \%$ & $15.02 \%$ & $15.87 \%$ & $17.47 \%$ & $18.72 \%$ & $17.62 \%$ & $17.41 \%$ & $17.26 \%$ & $15.64 \%$ & $16.47 \%$ & $16.30 \%$ & $13.92 \%$ & $13.49 \%$ \\
\hline Potatoes & $2.77 \%$ & $2.27 \%$ & $2.47 \%$ & $2.64 \%$ & $2.53 \%$ & $2.46 \%$ & $2.38 \%$ & $2.54 \%$ & $2.77 \%$ & $2.05 \%$ & $2.02 \%$ & $2.07 \%$ & $1.98 \%$ & $2.09 \%$ & $2.05 \%$ & $1.96 \%$ \\
\hline
\end{tabular}

\begin{tabular}{c|c} 
Potatoes & 2.77 \\
\hline Source: EUROST
\end{tabular} 